CLINICAL STUDY

\title{
Treatment of gonadotropin-deficient boys with recombinant human FSH: long-term observation and outcome
}

\author{
Taneli Raivio, Anne M Wikström and Leo Dunkel ${ }^{1}$ \\ Hospital for Children and Adolescents, Helsinki University Central Hospital, University of Helsinki, Helsinki, Finland and ${ }^{1}$ Department of Pediatrics, Kuopio \\ University Hospital, University of Kuopio, Kuopio, Finland
}

(Correspondence should be addressed to T Raivio who is now at Reproductive Endocrine Unit, BHX 511, Massachusetts General Hospital, 55 Fruit Street, Boston, Massachusetts 02114, USA; Email: traivio@gmail.com)

\begin{abstract}
Background: Boys with prepubertal onset of hypogonadotropic hypogonadism (HH) are at a risk of poor testis growth and impaired spermatogenesis. One potential cause for this is deficient proliferation of immature Sertoli cells before and during puberty due to the absence of FSH.

Objective: To evaluate the effects of recombinant human FSH (r-hFSH) and human chorionicgonadotropin (hCG) on testicular function and pubertal development in boys with prepubertal onset of $\mathrm{HH}$. Design: Retrospective clinical study.

Setting: Two university central hospitals, pediatric referral endocrinology outpatient clinics.

Patients: Fourteen boys (aged, 9.9-17.7 years) with prepubertal (testicular volume (TV) $<3 \mathrm{ml}$ ) onset of $\mathrm{HH}$ (idiopathic $\mathrm{HH}, n=2$; Kallman syndrome, $n=2$; idiopathic panhypopituitarism, $n=4$; organic panhypopituitarism, $n=6$ ).

Intervention: Treatment with r-hFSH alone ( 2 mo-2.8 years) prior to induction of puberty with the combination of FSH and hCG.

Main outcome measures: Progression of puberty, change in serum inhibin B, spermatogenesis.

Results: r-hFSH alone increased testicular volume twofold, from $0.9 \pm 0.6 \mathrm{ml}$ (mean \pm s.D.) to $1.8 \pm$ $1.1 \mathrm{ml}(P<0.005)$, and serum inhibin B threefold, from $27 \pm 14$ to $80 \pm 57 \mathrm{pg} / \mathrm{ml}(P<0.01)$. Three boys with an apparent absence of postnatal hypothalamic-pituitary-testicular axis activation displayed attenuated inhibin B responses to long-term $(\geq 1$ year) r-hFSH $(P<0.01)$. Further significant increase in both TV and inhibin B occurred with induction of puberty with FSH and hCG $(P<0.001)$. Seven boys provided semen samples: one had azoospermia, and others displayed a maximal sperm count range from 2.9 to $92 \mathrm{million} / \mathrm{ml}$ (median $8.5 \mathrm{million} / \mathrm{ml}$ ).

Conclusions: (i) r-hFSH induces prepubertal testis growth and increases circulating inhibin B levels, findings suggesting proliferation of immature Sertoli cells. (ii) Puberty was successfully induced with hCG and r-hFSH following r-hFSH priming. (iii) Inhibin B appears useful for monitoring spermatogenetic activity in boys treated with hCG. (iv) Despite the extremely small initial testis volume, six out of seven patients $(86 \%)$ primed with r-hFSH displayed sperm in the ejaculate suggesting beneficial effect of $\mathrm{r}$-hFSH priming on testicular function later in life.
\end{abstract}

European Journal of Endocrinology 156 105-111

\section{Introduction}

Boys with prepubertal onset of hypogonadotropic hypogonadism $(\mathrm{HH})$ require testosterone, pulsatile gonadotropin-releasing hormone $(\mathrm{GnRH})$, or gonadotropin treatment for induction of puberty. Testosterone treatment aims at virilization and does not induce spermatogenesis, whereas pulsatile GnRH and gonadotropin treatments to some extent compensate for the missing gonadotropin stimulus for the developing testis.

After birth, Sertoli cells proliferate during the first few months of life and in early puberty (1). Under experimental conditions, follicle-stimulating hormone (FSH) stimulates proliferation of immature Sertoli cells $(2,3)$. Observations in humans with one of the described gene defects, impairing FSH action (4-6) also suggest that FSH is required for the development of the Sertoli cell population. The number of Sertoli cells is directly associated with sperm-producing capacity, since each of these somatic cells can nurture only a limited number of developing spermatogenetic cells (7). In agreement with these findings, men with idiopathic $\mathrm{HH}(\mathrm{IHH})$ and lack of prior endogenous puberty display poor response to pulsatile GnRH in terms of testicular growth and spermatogenesis (8). We have previously introduced a novel treatment for prepubertal boys with $\mathrm{HH}$ with recombinant human FSH (r-hFSH) (9), which aims at increasing sperm-producing capacity by inducing immature Sertoli cell proliferation. In this work, we describe long-term results achieved in boys with prepubertal 
onset of HH treated with r-hFSH before induction of puberty with human chorionic gonadotropin (hCG).

\section{Patients and methods}

Data were retrospectively collected from patient files of fourteen boys (aged, 9.9-17.7 years) with prepubertal onset of HH treated between 1995 and 2005 at the Hospital for Children and Adolescents, University of Helsinki, or at Kuopio University Hospital. Clinical and hormonal data for some of these boys have been published in part previously (9-11). Two boys had IHH, two had Kallman syndrome (KS; IHH and hyposmia or anosmia based on anamnesis), four had idiopathic panhypopituitarism (other pituitary hormone deficiencies were adequately substituted), and six had an acquired form of panhypopituitarism and $\mathrm{HH}$ due to treatment of an intracranial tumor affecting the pituitary or hypothalamic region (craniopharyngioma, $n=4$; pilocytic astrocytoma, $n=2$ ) (Table 1). Diagnosis of $\mathrm{HH}$ was established by clinical history, physical examination, and subnormal gonadotropin responses to GnRH stimulation. All boys had low serum testosterone levels. Before induction of virilization, the boys were treated with r-hFSH (Gonal-f, Serono; Puregon, Organon) in 3 weekly s.c. doses starting from $1.5 \mathrm{IU} / \mathrm{kg}$ (range 180-450 IU/week) for $2 \mathrm{mo}-2.8$ years. Puberty was then induced by hCG (Profasi HP, Serono, Aubonne, Switzerland; Pregnyl, Organon, Oss, The Netherlands) (range from $500 \mathrm{IU}$ per 2 weeks to 4000 IU per week, 1-3 times per week s.c.). After the onset of hCG treatment, r-hFSH in some patients was changed to highly purified FSH (Fertinorm HP, Serono). During the course of treatment, the boys visited the outpatient clinic at 3- to 6-mo intervals.

Puberty was assessed according to Tanner (12) and testis length and width were measured with a ruler to the nearest millimeter; testis volume in $\mathrm{ml}$ was calculated by the formula (length $\times$ width $\times$ width $\times 0.52$ ) (13). Serum gonadotropin levels were measured as described elsewhere $(11,14)$. Serum inhibin B levels were obtained from previous studies $(9,11)$ or measured with a commercially available immunoassay (Serotec, Oxford, UK) with sensitivity $<15.6 \mathrm{pg} / \mathrm{ml}$, within-assay coefficient of variation $(\mathrm{CV})<5 \%$, and between-assay $\mathrm{CV} \leq 14 \%$ at 82 or $219 \mathrm{pg} / \mathrm{ml}$ and $19.7 \%$ at a mean level of $41 \mathrm{pg} / \mathrm{ml}$. Semen analyses were performed according to the World Health Organization guidelines (15). The review of the patient files was approved by the ethics committee of the hospital.

\section{Statistical analysis}

Because the same subjects were investigated repeatedly, we employed the technique of summary methods (16); to assess testicular responsiveness to r-hFSH and to FSH plus hCG, the highest inhibin B value for each patient during the respective treatment period served as the raw data in paired t tests. Similarly, average testis volume (or volume of the right or left testis if the average volume of both testes was unavailable) during the r-hFSH and the FSH plus hCG treatment was calculated for each subject, serving as the raw data in paired $t$ tests. The Spearman rank correlation coefficient was calculated between sperm counts and serum inhibin B levels. $P<0.05$ was considered to indicate statistical significance.

\section{Results}

\section{Effect of gonadotropin treatment on serum inhibin B levels and testis volume}

Subjects in this series received r-hFSH treatment for 2 mo-2.8 years. The length of r-hFSH treatment correlated negatively with the age of the patient at the start of treatment $(r=-0.78, n=14, P<0.001$; Table 1$)$. The $\mathrm{r}-\mathrm{hFSH}$ increased serum inhibin B from (mean \pm s.D.) $27 \pm 14$ to $80 \pm 57 \mathrm{pg} / \mathrm{ml}$ (maximal value in each patient observed during r-hFSH $)(P<0.01)$ and testicular size from $0.9 \pm 0.7 \mathrm{ml}(n=12)$ to $1.8 \pm 1.1 \mathrm{ml}$ $(n=13) \quad(P<0.005$; mean of average testis volumes observed during treatment; Fig. 1). Further increases in both parameters were encountered in thirteen boys after addition of $\mathrm{hCG}$ to the regimen (Fig. $1 ; \mathrm{P}<0.001$ ). However, no unequivocal differences between patients with different etiologies of $\mathrm{HH}$ were observed (Fig. 2). The maximal inhibin B levels observed during treatments with r-hFSH alone or with FSH plus hCG correlated strongly with each other $\left(r_{s}=0.87, P<0.005, n=13\right)$ and with average testis volumes measured during these treatment periods $\left(\mathrm{r}_{\mathrm{s}}=0.75, P<0.01, n=13\right.$, and $r_{s}=0.67, P<0.05, n=13$ respectively).

Nine boys received $\mathrm{r}$-hFSH $\geq 1$ year before the onset of hCG treatment (Table 1). Three of these subjects had significantly lower peak inhibin B responses to r-hFSH $(P<0.01)$ when compared with the other six boys (indicated with arrows in Fig. 2B) and tended to have smaller testes during the treatment $(2.3 \pm 1.2$ vs $0.8 \pm$ $0.2 \mathrm{ml}, P=0.08$ ). Based on serum FSH levels during the treatment, this difference in inhibin B response was not attributed to compliance between these subgroups (data not shown). Although, all these three boys (patients 4 , 8, and 11 in Table 1) had different etiologies of $\mathrm{HH}$, their clinical histories revealed an apparent absence of postnatal activation of the hypothalamic-pituitarytesticular (HPT) axis: craniopharyngioma operated on shortly after birth resulting in panhypopituitarism (patient 11 in Table 1), KS (subject 4) or panhypopituitarism (patient 8), patients 4 and 8 both had histories of microphallus and bilateral cryptorchidism.

\section{Progression of puberty during gonadotropin treatment}

Progression of puberty during the treatment with r-hFSH or FSH plus hCG in fourteen boys with prepubertal onset 
Table 1 Clinical characteristics and spermatogenesis parameters in patients with prepubertal onset of hypogonadotropic hypogonadism.

\begin{tabular}{|c|c|c|c|c|c|c|c|c|c|}
\hline \multirow[b]{3}{*}{ Patient no. } & \multirow[b]{3}{*}{ Diagnosis (age at treatment) } & \multirow{3}{*}{$\begin{array}{l}\text { History of bilateral } \\
\text { cryptorchidism and } \\
\text { underdeveloped phallus }\end{array}$} & \multirow{3}{*}{$\begin{array}{l}\text { Serum FSH (IU/l) } \\
\text { /inhibin B (pg/ml) } \\
\text { prior to r-hFSH Rx }\end{array}$} & \multicolumn{2}{|c|}{ r-hFSH Rx } & \multicolumn{4}{|c|}{ Spermatogenesis } \\
\hline & & & & \multirow[b]{2}{*}{$\begin{array}{l}\text { Age } \\
\text { at onset }\end{array}$} & \multirow[b]{2}{*}{ Duration } & \multirow[b]{2}{*}{$\begin{array}{l}\text { Max. sperm count } \\
\quad(\text { million } / \mathrm{ml})\end{array}$} & \multirow[b]{2}{*}{$\begin{array}{l}\text { Ejaculate } \\
\text { vol }(\mathrm{ml})\end{array}$} & \multicolumn{2}{|c|}{ Sperm motility $^{\mathrm{a}}$} \\
\hline & & & & & & & & $A(\%)$ & B (\%) \\
\hline 1 & $\mathrm{IHH}$ & No & $0.4 / 45$ & 17.7 & 2 months & 5 & 3 & 2 & 57 \\
\hline 2 & $\mathrm{IHH}$ & No & $1.4 / 21$ & 15.5 & 6 months & 12 & 2 & 24 & 46 \\
\hline 3 & KS & Yes & $<0.1 /<15.6$ & 12.9 & 3 months & 0 & 0.4 & 0 & 0 \\
\hline 4 & KS & Yes & $0.1 /<15.6$ & 10.3 & 1.4 years & 2.9 & 1.5 & 5 & 32 \\
\hline 5 & Pan & No & $0.4 / 16$ & 13.2 & 1 year & & & & \\
\hline 6 & Pan & No & $0.1 / 20$ & 13.7 & 8 months & & & & \\
\hline 7 & Pan & No & $0.1 / 49$ & 12.8 & 1 year & 3.5 & 1.5 & 4 & 73 \\
\hline 8 & Pan & Yes & $<0.1 /<15.6$ & 10.3 & 2.8 years & & & & \\
\hline 9 & $\begin{array}{l}\text { Pilocytic astrocytoma }{ }^{\mathrm{b}} \\
\quad \text { (iodine implants at } 6 \text { years) }\end{array}$ & No & $<0.1 / 20$ & 10.0 & 1.4 years & & & & \\
\hline 10 & $\begin{array}{l}\text { Craniopharyngioma } \\
\quad \text { (operation at } 10 \text { years) }\end{array}$ & No & $0.7 / 53$ & 13.2 & 1 years & 92 & 1 & 43 & 32 \\
\hline 11 & $\begin{array}{l}\text { Craniopharyngioma } \\
\text { (operation after birth) }\end{array}$ & No & $<0.1 /<15.6$ & 10.0 & 2.5 years & & & & \\
\hline 12 & $\begin{array}{l}\text { Pilocytic astrocytoma }{ }^{b^{\prime}} \\
\quad \text { (operation at } 12 \text { years) }\end{array}$ & No & $<0.1 / 42$ & 13.2 & 1.1 years & 15 & 0.8 & 7 & 47 \\
\hline 13 & $\begin{array}{l}\text { Craniopharyngioma } \\
\text { (operation at } 5 \text { years) }^{\mathrm{b}}\end{array}$ & No & $<0.1 / 38$ & 10.4 & 2.8 years & & & & \\
\hline 14 & $\begin{array}{l}\text { Craniopharyngioma } \\
\text { (operation at } 6 \text { years) }\end{array}$ & No & $<0.1 / 18$ & 12.9 & 6 months & & & & \\
\hline
\end{tabular}

$\mathrm{IHH}$, idiopathic hypogonadotropic hypogonadism; KS, Kallman syndrome; Pan, idiopathic panhypopituitarism; FSH, follicle-stimulating hormone.

${ }^{a}$ See reference (15); ${ }^{b}$ panhypopituitarism following treatment of an intracranial tumor. 

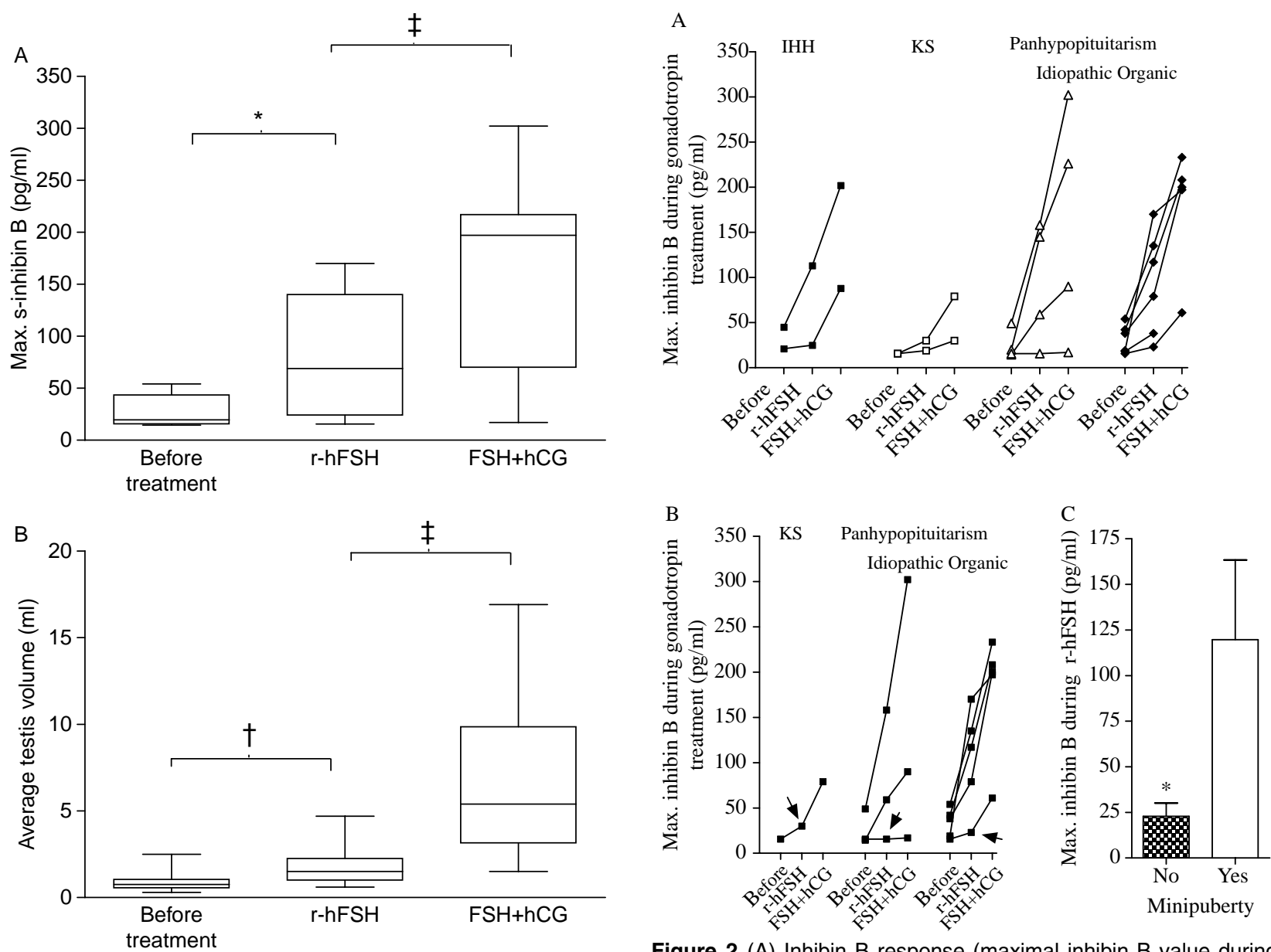

Figure 1 Effect of recombinant human follicle-stimulating hormone $(\mathrm{r}-\mathrm{hFSH})$ and $\mathrm{FSH}+$ human chorionic gonadotropin (hCG) treatments on (A) serum inhibin $B$ levels and $(B)$ testis volume in fourteen boys with prepubertal onset of gonadotropin deficiency. ${ }^{*} P<0.01$; ${ }^{\dagger} P<0.005 ;{ }^{\ddagger} P<0.001$.

of $\mathrm{HH}$ is shown in Fig. 3. Expectedly, as compared to healthy Finnish boys (17), the onset of puberty in boys with $\mathrm{HH}$ was sometimes delayed. This was related to delayed diagnosis and/or start of treatment. Once treatments were started, however, genital development progressed at a normal rate (Fig. 3). Some boys displayed slow growth of pubic hair (Fig. 3).

\section{Longitudinal data on three patients}

Figure 4 shows individual longitudinal data on three patients treated with r-hFSH before induction of puberty with hCG providing novel aspects of testicular physiology. Patient 9 (Table 1) had pilocytic astrocytoma detected at the age of 3 years and subsequently treated with iodine implants. He received r-hFSH from the age of 10 to 11.5 years, resulting in testis growth and increased serum inhibin B (Fig. 4A). After cessation of r-hFSH, however, both parameters decreased. During the combined treatment with FSH and hCG, testis volume and serum inhibin B level increased markedly.

Figure 2 (A) Inhibin B response (maximal inhibin $B$ value during treatment) to $\mathrm{r}$-hFSH and FSH + hCG treatment in fourteenprepubertal boys with hypogonadotropic hypogonadism $(\mathrm{HH})$ (IHH, idiopathic HH; KS, Kallman syndrome; Pan, panhypopituitarism). (B) Inhibin B responses to $\mathrm{r}-\mathrm{hFSH}$ in nine boys who received $\mathrm{r}$-hFSH treatment for 1 year or longer, arrows indicate the three poorest responders to $\mathrm{r}$-hFSH. These boys with evidence of absent postnatal activation of the hypothalamic-pituitary-testicular axis (minipuberty) had significantly lower peak inhibin B values $\left({ }^{\star} P<0.01\right)$ in response to $\mathrm{r}-\mathrm{hFSH}$ than the other six boys $(\mathrm{C})$.

Patient 10 (Table 1) had panhypopituitarism due to a craniopharyngioma operated on at the age of 10 years. His testicular volume and inhibin B levels increased during the r-hFSH treatment (9). After addition of hCG to the regimen, testicular volume further increased (Fig. 4B). One and a half years after the start of hCG treatment, spermatozoa were found in semen samples; this was followed by a substantial increase in serum inhibin B and an improvement in sperm count (Fig. 4B). Patient 10 ultimately achieved a normal sperm count that interestingly was sustained after cessation of FSH, with hCG alone.

Patient 7 (Table 1) (9) had idiopathic panhypopituitarism. His inhibin B level increased in response to r-hFSH, and a further increase was observed after addition of hCG to the regimen. However, inhibin B levels decreased continuously during the course of FSH plus hCG therapy. After 8.5 years of gonadotropin 

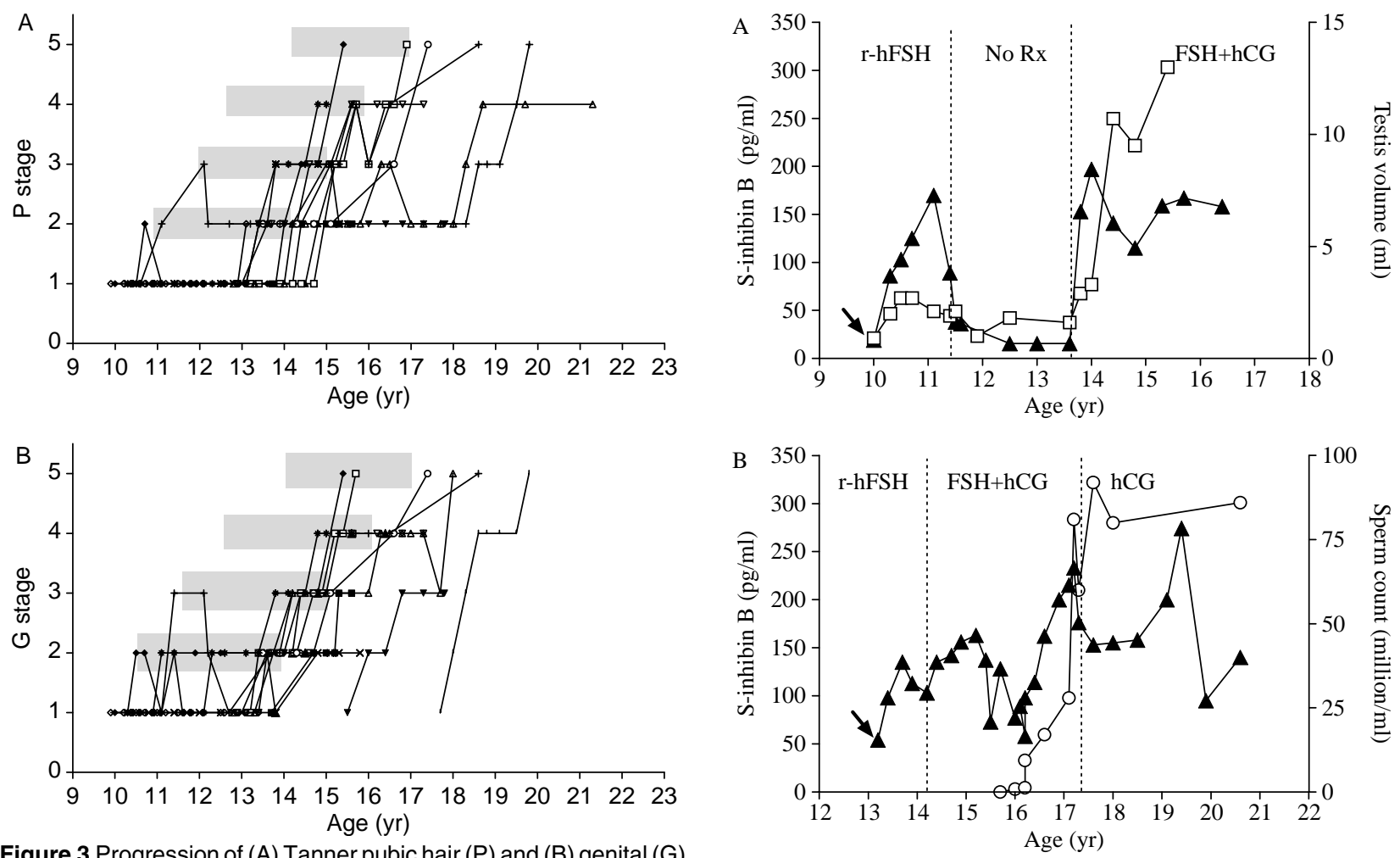

Figure 3 Progression of $(A)$ Tanner pubic hair $(P)$ and $(B)$ genital $(G)$
stages in fourteen boys with prepubertal onset of hypogonadotropic hypogonadism (lines) treated with r-hFSH and subsequently with FSH and hCG. Gray boxes, mean \pm 2 s.D. of pubertal stages in healthy Finnish boys (17).

treatment, he provided the first semen sample for possible future use; this sample contained sperm in the ejaculate (Fig. 4C). Subsequent samples showed improvement in the sperm count (Fig. 4C).

\section{Spermatogenesis}

During treatment with FSH and/or hCG, seven boys provided semen samples. The first ejaculate containing sperm for each subject was observed when testicular volume ranged from 6.2 to $14.4 \mathrm{ml}$, the Tanner $P$ stage ranged from $\mathrm{P} 3$ to $\mathrm{P} 6$ and the Tanner $\mathrm{G}$ stage was $\mathrm{G} 4$ or G5. Only one subject (patient 3, Table 1) displayed azoospermia, whereas the median of the maximal sperm count for the other six boys was $8.5 \mathrm{million} / \mathrm{ml}$ (range 2.9-92 million/ml) (Table 1). The pretreatment testicular volume correlated with maximal sperm count $(\mathrm{rs}=0.9$, $n=6, P<0.05$ ). Aliquots of the semen samples were frozen for possible future use.

\section{Discussion}

We describe progression of puberty, testicular responsiveness to gonadotropin therapy, and spermatogenesis in boys with prepubertal onset of $\mathrm{HH}$ primed with r-hFSH and subsequently treated with FSH and hCG.

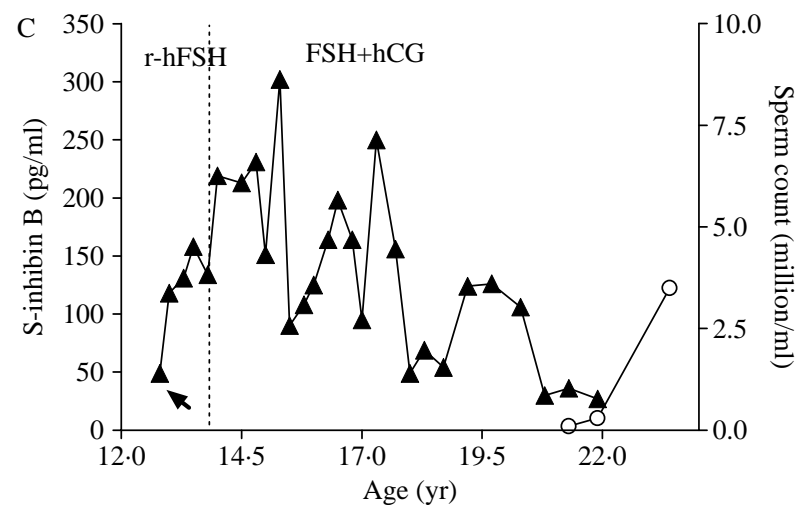

Figure 4 Longitudinal changes in serum inhibin $B$ levels $(\boldsymbol{A})$, testicular volume $(\square)$, and sperm count $(O)$ in three boys $(A-C)$ with prepubertal onset of gonadotropin deficiency treated with $\mathrm{r}$-hFSH, FSH combined with hCG, or hCG alone. A, patient 9 in Table 1; B, patient 10 in Table 1; C, patient 7 in Table 1.

To our knowledge, this is the first study describing the effect of prepubertal r-hFSH priming on testicular function later in life.

Although some boys displayed relatively slow progression of pubic hair growth, gonadotropin treatment induced puberty and genital development in all subjects. This is important because patients are often concerned about their lack of puberty and being different from their peers. The rationale of r-hFSH treatment, which sometimes may postpone virilization desired by the patient, is to induce proliferation of immature Sertoli cells before their number becomes fixed (9). As far as we are aware, there is currently only one preliminary work 
that describes histological findings following 4-mo of r-hFSH treatment: an increase in testis volume and serum inhibin B was accompanied by an increase in Sertoli cell and type A spermatogonia numbers (18). Our results suggest similar beneficial effects of r-hFSH treatment on the developing testis in boys.

During the first few months of life, the most profound postnatal proliferation of Sertoli cells occurs (1) and is accompanied by an increase in circulating inhibin B (19). In the current work, three boys with the poorest inhibin B responses to long-term r-hFSH treatment all had evidence of absent postnatal activation of the HPT axis (minipuberty), suggesting an impact of very early luteinizing hormone (LH), testosterone and FSH secretion on testicular responsiveness to gonadotropins later in life. This concept of earlier testicular development having an impact on treatment response later in life is in accord with observations in men with IHH (8). On the other hand, Young et al. (20) showed that shortterm r-hFSH administration to men with congenital forms of $\mathrm{HH}$ increased circulating inhibin B. However, the degree of HPT axis function during minipuberty in such patients has not been described in detail.

All patients in this series had small initial testicular volume $(<3 \mathrm{ml})$, which predicts a substantial risk for azoospermia, when employing conventional gonadotropin treatment protocols. For example, Miyagawa et al. (21) reported that only $36 \%$ of men with initial testis volume of $<4 \mathrm{ml}$ displayed sperm in the ejaculate after gonadotropin treatment. In our series, six of seven patients $(86 \%)$ primed with r-hFSH encouragingly displayed sperm in the ejaculate, and the one with azoospermia reported difficulties in providing the sample. Yet, r-hFSH treatment appeared not to have a dramatic impact on sperm counts, and our small patient series was heterogeneous in terms of etiology of $\mathrm{HH}$ and the presence or absence of cryptorchidism. Thus, randomized placebo-controlled studies are needed to evaluate the ultimate effect of peripubertal r-hFSH priming on future spermatogenesis.

Our data enable interesting observations on both testicular development and inhibin B in response to gonadotropins. First, the lack of minipuberty seemingly predicted poor prognosis for spermatogenesis, as patients 3 (3 mo of r-hFSH treatment) and 4 (1.4 years of r-hFSH treatment; Table 1) displayed the lowest sperm counts of all patients examined. It is tempting to speculate that these two patients would have benefited from FSH and LH treatments during the first year of life (22).

Indeed, recent evidence from elegant rodent (23) and nonhuman primate (3) models suggest that not only FSH, but also androgens and/or LH can induce Sertoli cell proliferation. Second, the continuous increase in sperm count in patient 10 was followed by a sustained increase in serum inhibin B, a finding in agreement with the concept that inhibin B in men is a joint product of germ cells and Sertoli cells (24). However, additional complexity comes from the recent evidence suggesting that not only cells within the seminiferous tubules, but also Leydig cells significantly contribute to circulating inhibin B in boys (25). A role of Leydig cells in the production of inhibin B, either directly or through induction of spermatogenesis, is in agreement with our findings showing higher inhibin B levels during hCG plus FSH regimen as compared to FSH alone. It is noteworthy that FSH induces LH receptor expression (26). Third, in patient 7 (Table 1), long-term treatment with hCG was associated with a decline in serum inhibin B. The hCG may cause intratesticular bleeding (27) and inflammation-like changes within the gonad (28) and induce apoptosis of germ cells $(29,30)$. Moreover, patients with $\mathrm{HH}$ may develop antibodies against hCG $(31,32)$. While pulsatile GnRH or recombinant LH treatment might have provided more physiological means of inducing virilization and fertility than hCG, patient 10 still achieved a normal sperm count that was maintained with hCG alone. Thus, whether the decline in serum inhibin B in this patient reflected intratesticular pathology is unclear. Further studies are clearly needed to address this issue.

Given that men with HH may naturally conceive their partners with a very low sperm count (33), and that intracytoplasmic sperm injection (ICSI) has been successfully used in men with $\mathrm{HH}$, who remain azoospermic after gonadotropin treatment (34), the rationale for an attempt to increase sperm-producing capacity with r-hFSH priming in boys with prepubertal onset of $\mathrm{HH}$ may be questioned. However, ICSI has not completely solved the infertility problem among men with $\mathrm{HH}$ (35) and pregnancy rate per ICSI cycle in men with $\mathrm{HH}$ is lower in obstructive cases (17.6 vs $34.5 \%$ ) (34). Therefore, we feel that treatments aiming at improving of endogenous testicular function are justified.

In conclusion, (i) r-hFSH induces prepubertal testis growth and increases circulating inhibin B levels, findings suggesting proliferation of immature Sertoli cells. (ii) Puberty was successfully induced with hCG and r-hFSH following r-hFSH priming. (iii) Inhibin B appears useful for monitoring spermatogenetic activity in boys treated with hCG. (iv) Despite the extremely small initial testis volume, six out of seven patients $(86 \%)$ primed with r-hFSH displayed sperm in the ejaculate suggesting beneficial effect of r-hFSH priming on testicular function later in life.

\section{Acknowledgements}

This work was supported by the Foundation for Pediatric Research and Paulo Foundation.

\section{References}

1 Cortes D, Muller J \& Skakkebaek NE. Proliferation of Sertoli cells during development of the human testis assessed by stereological methods. International Journal of Andrology $1987 \mathbf{1 0} 589-596$. 
2 Orth JM, Gunsalus GL \& Lamperti AA. Evidence from Sertoli celldepleted rats indicates that spermatid number in adults depends on numbers of Sertoli cells produced during perinatal development. Endocrinology 1988122 787-794.

3 Ramaswamy S, Plant TM \& Marshall GR. Pulsatile stimulation with recombinant single chain human luteinizing hormone elicits precocious sertoli cell proliferation in the juvenile male rhesus monkey (Macaca mulatta). Biology of Reproduction 200063 82-88.

4 Tapanainen JS, Aittomaki K, Min J, Vaskivuo T \& Huhtaniemi IT. Men homozygous for an inactivating mutation of the folliclestimulating hormone (FSH) receptor gene present variable suppression of spermatogenesis and fertility. Nature Genetics $199715205-206$.

5 Lindstedt G, Nystrom E, Matthews C, Ernest I, Janson PO \& Chatterjee K. Follitropin (FSH) deficiency in an infertile male due to FSHbeta gene mutation. A syndrome of normal puberty and virilization but underdeveloped testicles with azoospermia, low FSH but high lutropin and normal serum testosterone concentrations. Clinical Chemistry and Laboratory Medicine 199836 663-665.

6 Phillip M, Arbelle JE, Segev Y \& Parvari R. Male hypogonadism due to a mutation in the gene for the beta-subunit of follicle-stimulating hormone. New England Journal of Medicine 1998338 1729-1732.

7 Johnson L, Zane RS, Petty CS \& Neaves WB. Quantification of the human Sertoli cell population: its distribution, relation to germ cell numbers, and age-related decline. Biology of Reproduction 198431 785-795.

8 Pitteloud N, Hayes FJ, Boepple PA, DeCruz S, Seminara SB, MacLaughlin DT \& Crowley WF Jr. The role of prior pubertal development, biochemical markers of testicular maturation, and genetics in elucidating the phenotypic heterogeneity of idiopathic hypogonadotropic hypogonadism. Journal of Clinical Endocrinology and Metabolism $2002 \mathbf{8 7} 152-160$.

9 Raivio T, Toppari J, Perheentupa A, McNeilly AS \& Dunkel L. Treatment of prepubertal gonadotrophin-deficient boys with recombinant human follicle-stimulating hormone. Lancet 1997 350 263-264.

10 Raivio T. Endocrine Interaction Between the Developing Testis and the Pituitary Gland in Healthy and Hypogonadal Boys, p. 51 Helsinki: University of Helsinki, 1999.

11 Raivio T, Saukkonen S, Jaaskelainen J, Komulainen J \& Dunkel L. Signaling between the pituitary gland and the testes: inverse relationship between serum $\mathrm{FSH}$ and inhibin B concentrations in boys in early puberty. European Journal of Endocrinology 2000142 150-156.

12 J Tanner, Oxford: Blackwell, Inc., 1962.

13 Hansen PF \& With TK. Clinical measurements of the testes in boys and men. Acta Medica Scandinavica. Supplementum, 1952 457-465.

14 Dunkel L, Alfthan H, Stenman UH \& Perheentupa J. Gonadal control of pulsatile secretion of luteinizing hormone and folliclestimulating hormone in prepubertal boys evaluated by ultrasensitive time-resolved immunofluorometric assays. Journal of Clinical Endocrinology and Metabolism 199070 107-114.

15 World Health Organization. WHO Laboratory Manual for the Examination of Human Semen and Sperm-Cervical Mucus Interaction Cambridge: Cambridge University, 1999.

16 Matthews JN, Altman DG, Campbell MJ \& Royston P. Analysis of serial measurements in medical research. BMJ 1990300 230-235.

17 Ojajärvi P. The Adolescent Finnish Child, A Longitudinal Study of the Anthropometry, Physical Development and Physiological Changes During Puberty Helsinki: University of Helsinki, 1982.

18 Pitteloud N, Dwyer A, Hayes FJ, Kumar P, Dym M \& Crowley WF Jr. The role of FSH in human testicular development. Endo 2005 Abstract Book, San Diego 4-7 2005 P1-P559.

19 Andersson AM, Toppari J, Haavisto AM, Petersen JH, Simell T, Simell O \& Skakkebaek NE. Longitudinal reproductive hormone profiles in infants: peak of inhibin B levels in infant boys exceeds levels in adult men. Journal of Clinical Endocrinology and Metabolism 199883 675-681.

20 Young J, Chanson P, Salenave S, Noel M, Brailly S, O’Flaherty M, Schaison G \& Rey R. Testicular anti-mullerian hormone secretion is stimulated by recombinant human FSH in patients with congenital hypogonadotropic hypogonadism. Journal of Clinical Endocrinology and Metabolism 200590 724-728.

21 Miyagawa Y, Tsujimura A, Matsumiya K, Takao T, Tohda A, Koga M, Takeyama M, Fujioka H, Takada S, Koide T \& Okuyama A. Outcome of gonadotropin therapy for male hypogonadotropic hypogonadism at university affiliated male infertility centers: a 30-year retrospective study. Journal of Urology $2005 \mathbf{1 7 3}$ 2072-2075.

22 Main KM, Schmidt IM, Toppari J \& Skakkebaek NE. Early postnatal treatment of hypogonadotropic hypogonadism with recombinant human FSH and LH. European Journal of Endocrinology 2002146 75-79.

23 Tan KA, De Gendt K, Atanassova N, Walker M, Sharpe RM, Saunders PT, Denolet E \& Verhoeven G. The role of androgens in sertoli cell proliferation and functional maturation: studies in mice with total or sertoli cell-selective ablation of the androgen receptor. Endocrinology $20051462674-2683$.

24 Andersson AM, Muller J \& Skakkebaek NE. Different roles of prepubertal and postpubertal germ cells and Sertoli cells in the regulation of serum inhibin B levels. Journal of Clinical Endocrinology and Metabolism $1998 \mathbf{8 3} 4451-4458$.

25 Soriano-Guillen L, Mitchell V, Carel JC, Barbet P, Roger M \& Lahlou N. Activating mutations in the Lh receptor gene: a human model of non fsh-dependent inhibin production and germ cell maturation. Journal of Clinical Endocrinology and Metabolism 2006 9 3041-3047.

26 Vihko KK, LaPolt PS, Nishimori K \& Hsueh AJ. Stimulatory effects of recombinant follicle-stimulating hormone on Leydig cell function and spermatogenesis in immature hypophysectomized rats. Endocrinology 1991129 1926-1932.

27 Kaleva M, Arsalo A, Louhimo I, Rapola J, Perheentupa J, Henriksen K \& Toppari J. Treatment with human chorionic gonadotrophin for cryptorchidism: clinical and histological effects. International Journal of Andrology 199619 293-298.

28 Hjertkvist M, Lackgren G, Ploen L \& Bergh A. Does HCG treatment induce inflammation-like changes in undescended testes in boys? Journal of Pediatric Surgery 199328 254-258.

29 Heiskanen P, Billig H, Toppari J, Kaleva M, Arsalo A, Rapola J \& Dunkel L. Apoptotic cell death in the normal and cryptorchid human testis: the effect of human chorionic gonadotropin on testicular cell survival. Pediatric Research $199640351-356$.

30 Dunkel L, Taskinen S, Hovatta O, Tilly JL \& Wikstrom S. Germ cell apoptosis after treatment of cryptorchidism with human chorionic gonadotropin is associated with impaired reproductive function in the adult. Journal of Clinical Investigation $19971002341-2346$.

31 Claustrat B, David L, Faure A \& Francois R. Development of antihuman chorionic gonadotropin antibodies in patients with hypogonadotropic hypogonadism. A study of four patients. Journal of Clinical Endocrinology and Metabolism $1983 \mathbf{5 7}$ 1041-1047.

32 Thau RB, Goldstein M, Yamamoto Y, Burrow GN, Phillips D \& Bardin CW. Failure of gonadotropin therapy secondary to chorionic gonadotropin-induced antibodies. Journal of Clinical Endocrinology and Metabolism 198866 862-867.

33 Burris AS, Clark RV, Vantman DJ \& Sherins RJ. A low sperm concentration does not preclude fertility in men with isolated hypogonadotropic hypogonadism after gonadotropin therapy. Fertility and Sterility $1988 \mathbf{5 0} 343-347$.

34 Fahmy I, Kamal A, Shamloul R, Mansour R, Serour G \& Aboulghar M. ICSI using testicular sperm in male hypogonadotrophic hypogonadism unresponsive to gonadotrophin therapy. Human Reproduction $2004191558-1561$.

35 Yong EL, Lee KO, Ng SC \& Ratnam SS. Induction of spermatogenesis in isolated hypogonadotrophic hypogonadism with gonadotrophins and early intervention with intracytoplasmic sperm injection. Human Reproduction 199712 1230-1232.

Received 16 June 2006

Accepted 11 October 2006 